\title{
Impact of Early Aggressive Nutrition on Retinal Development in Premature Infants
}

\author{
N. LENHARTOVA ${ }^{1}$, K. MATASOVA ${ }^{1}$, Z. LASABOVA $^{2,3}$, K. JAVORKA $^{3,4}$, \\ A. CALKOVSKA ${ }^{3,4}$
}

${ }^{1}$ Clinic of Neonatology, Jessenius Faculty of Medicine in Martin, Comenius University in Bratislava, Martin, Slovakia, ${ }^{2}$ Department of Molecular Biology, Jessenius Faculty of Medicine in Martin, Comenius University in Bratislava, Martin, Slovakia, ${ }^{3}$ Biomedical Center Martin, Jessenius Faculty of Medicine in Martin, Comenius University in Bratislava, Martin, Slovakia ${ }^{4}$ Department of Physiology, Jessenius Faculty of Medicine in Martin, Comenius University in Bratislava, Martin, Slovakia

Received April 22, 2017

Accepted April 30, 2017

\section{Summary}

The normal retinal development is interrupted by preterm birth and a retinopathy of prematurity (ROP) may develop as its consequence. ROP is characterised by aberrant vessel formation in the retina as a response to multiple risk factors influencing the process of retinal angiogenesis. Insulin-like growth factor I (IGF-1) and vascular endothelial growth factor (VEGF) play an important role in the process of normal retinal vascularisation. Insufficient nutrition during the first 4 postnatal weeks results in low serum levels of IGF-1, which is essential for correct retinal vessels formation, ensuring survival of the newly formed endothelial cells. Low IGF-1 level results in stop of angiogenesis in the retina, leaving it avascular and prompting the onset of ROP. Keeping the newborns in a positive energetic balance by providing enough nutrients and energy has a beneficial impact on their growth, neurodevelopment and decreased incidence of ROP. The best way to achieve this is the early parenteral nutrition with the high content of nutrients combined with early enteral feeding by the own mother's breast milk. Multiple studies confirmed the safety and efficacy of early aggressive nutrition but information about its long-term effects on the metabolism, growth and development is stil needed.

\section{Key words}

Nutrition • ROP • IGF-1 • Preterm infant

\section{Corresponding author}

K. Matasova, Clinic of Neonatology, Jessenius Faculty of Medicine in Martin, Comenius University in Bratislava, University Hospital, Kollarova 2, 03659 Martin, Slovakia. E-mail: matasova.katarina@gmail.com

\section{Introduction}

Retinopathy of prematurity (ROP) is a neovascular disease of the retina affecting extremely preterm infants born mostly before the 32-nd week of gestation with birth weight (BW) less than 1,500 grams (Wilkinson et al. 2008). Its onset is a result of interruption of normal retinal development which is caused by premature birth. The following aberrant vascularisation of retina can cause retinal scarring, detachment and subsequent blindness. With the gradual improvement in neonatal care, and thus an increase in the amount of surviving extremely premature babies, ROP remains the most prevalent cause of childhood blindness and vision impairment. It leads to approximately $15 \%$ of all cases of visual loss in developed countries and up to $60 \%$ in middle income countries (Gogate et al. 2011), where approximately one third of very low birth weight infants develop some form of ROP (Cavallaro et al. 2014). While the incidence of ROP in developed 
countries is $5-8 \%$, it raises up to $30 \%$ in mediumdeveloped countries (Gergely and Gerinec 2010), probably due to limited financial resources. The incidence also increases with decreasing gestational age (GA) and birth weight (BW).

Multiple risk factors have been confirmed or strongly suggested for the onset of ROP. Prematurity is considered to be the main risk factor, followed by hyperoxia and unstable saturation, possible genetic predisposition, gender and race, hyperglycemia, multiple blood transfusions, administration of erythropoietin (EPO) and also nutritional status along with low BW. This multifactoriality makes its prevention and management complicated. Better understanding of the patophysiology of ROP has allowed various preventive strategies to be devised and implemented, targeting some of the important risk factors. Currently, appropriate nutrition in preterm infants and its influence on retinal maturation is accentuated. Nutritional support as a part of postnatal care is relatively well controllable and the connection between poor nutrition, slowed postnatal growth, and the development of ROP has been estabilished in multiple studies (Van der Veen et al. 2013, Stoltz Sjöström et al. 2016, Porcelli and Weaver 2010, Wu et al. 2012, Hellström et al. 2010). By providing an appropriate nutrition and avoiding extrauterine growth restriction in extremely preterm infants we can eliminate one of the many factors contributing to this disease.

\section{Normal versus pathological development of retina}

The development of retina starts during the fourth month and continues into the 40th week of gestation. An extremely premature infant is therefore born with incomplete retinal vasculature. Retinal blood vessels grow from the middle of the optic disk outwards to reach the ora serrata while the periphery stays avascular until approximately 32 nd week of gestation. This retinal tissue is then in a state of relative hypoxia, which acts as a stimulus for hypoxia-inducible factors (HIFs) to trigger the transcription of angiogenic genes to produce growth factors, such as VEGF, its analog placental growth factor (PIGF) and the proangiogenic EPO. VEGF follows this wave of physiological tissue hypoxia and stimulates production of new endothelial cells (vasculogenesis) and subsequent budding of new blood vessles from these cells (angiogenesis) (Hartnett
2015). VEGF-mediated vascularisation is controlled by IGF-1, which is essential for the survival and proliferation of the new endothelial cells (Hård et al. 2013). The synthesis of IGF-I is regulated by the availability of amino acids and depends on overall energy intake. It would therefore be safe to say that IGF-1 levels reflect the state of nutrition. During the third trimester, when sufficient nutrition is available, the levels normally increase two to three times, promoting protein accretion and fast fetal growth (Fowden 2003).

This carefully organised process needs the intrauterine environment to unfold correctly. The maternal-fetal interaction in utero provides suitable oxygen levels stimulating the growth of retinal vasculature, optimal nutrition for rapid growth and development and other factors unique to the intrauterine environment. The amniotic fluid itself is not only a cushioning medium; it contains lipids, carbohydrates, enyzmes, essential amino acids, which diffuse in through the placental membranes. Various growth factors are also present in levels comparable to those in maternal breast milk, including IGF-1 and EPO. The periodic ingestion of amniotic fluid promotes the development of the fetal gut and has positive influence on birth weight (Underwood et al. 2005, Underwood 2013).

With preterm birth, the infant suddenly loses these optimal conditions and has to cope with the harsh extrauterine environment, which it is poorly adapted for. The relative hyperoxia inhibits the expression of HIFs and VEGF, interrupting the growth of retinal blood vessels. Extremely premature newborns usually require oxygen during stabilisation or resuscitation after birth and many of them need further oxygen therapy, often lasting for days. ROP belongs to the group of neonatal free radical diseases, since the retinal tissue itself is highly susceptible to oxidative injury with its high oxygen consumption, constant exposure to light and rich content of easily oxidisable LCPUFA (long-chain polyunsaturated fatty acids), mainly DHA (docosahexaenoid acid) (Kim and Byzova 2014). Premature infants are also deficient in antioxidant defense to counterbalance this reactive oxygen species (ROS) increase (Sapieha et al. 2010). Oxidative stress resulting from inflammatory response during infection and sepsis or from long term parenteral nutrition also contributes to the retinal tissue injury. Fluctuations in oxygen saturation seem to be more damaging than sustained hyperoxia. It has been suggested, that it takes no more than six intermittent hypoxia episodes and subsequent 
reoxygenation for the accumulation of ROS in the choroid, causing irreversible oxidative damage to the retina in newborn rats (Beharry et al. 2013). Aimed to minimise the oxidative injury in preterm babies receiving oxygen, the saturation targets are recommended to be between 90 and $94 \%$ (Sweet et al. 2016).

After birth, as the infant loses the feto-maternal interaction, the levels of IGF-1 drop significantly. If a prolonged undernutrition follows, its increase is slow and insufficient resulting in growth restriction and higher vulnerability to ROP development. Fetal serum IGF-1 levels have been reported to correlate with birth weight, which is considered to be one of the risk factors of ROP. IGF-1 levels in small for gestational age (SGA) newborns were lower than those in eutrophic newborns (Lassarre et al. 1991). Interestingly, a positive correlation between intrauterine growth restriction and incidence of ROP was reported. Among the infants with ROP there was a higher number of SGA newborns compared to group without ROP - $32 \%$ vs. $19 \%$, respectively (Darlow et al. 2005, Allegaert et al. 2003).

The important role of IGF-1 in the normal development of retinal vasculature and its close relation to nutritional status of the infant explain the urgent need for appropriate nutrition in preterm newborns. The adequate nutrition is reflected by postnatal weight gain and head growth. Poor weight gain, especially during the first 4 weeks of postnatal life, has been identified as a strong independent risk factor in the onset of ROP (Porcelli and Weaver 2010). Slow postnatal head growth has also been suggested to coincide with retinal vascular suppression; however more studies are needed (Löfqvist et al. 2006).

\section{Development of ROP}

ROP develops in two phases: The first phase is vasoobliterative, caused by interrupted and delayed angiogenesis. The levels of HIF, VEGF, IGF-1 and EPO are all decreased during this phase (Cavallaro et al. 2014). As the newborn grows, there is an increase in metabolic demands and the retina starts to experience hypoxia, which upregulates the synthesis of VEGF with its subsequent accumulation in the retina and the vitreous body. If the nutrition is insufficient at this stage, serum levels of IGF-1 are low and angiogenesis does not occur effectively even if VEGF is present, since without IGF-1 the endothelial cells undergo excessive apoptosis (Hellström et al. 2001). When the serum IGF-1 catches up and rises to its treshold level, it prompts a transition into the second, vasoproliferative phase of ROP at around 32-34 weeks of postconceptional age. Rapid pathological neoangiogenesis is triggered manifesting at first as a faint demarcation line between the vascular and avascular retina - stage 1 according to International Committee For The Classification of Retinopathy of Prematurity (2005), then raising this junction into a ridge - stage 2 . These first two stages can regress spontaneously and are considered as early or mild ROP. The pathological vasculature can continue growing outside the retinal plane - stage 3, the vascular stage. These new blood vessels are subpar and fragile and can bleed into the vitreous body which causes fibrotisation, traction and finally retinal detachement resulting in blindness stages 4 and 5 , the fibrovascular stage.

\section{Aggressive early nutrition and its impact on retinal development}

A sufficient caloric intake and adequate amount of nutrients can prevent the postnatal gap in weight gain and IGF-1 levels and thus promote the catch-up growth and development in preterm infants. The current guidelines emphasise the importance of optimal nutrition similar to that in utero by starting the aggressive balanced parenteral nutrition and initiating enteral feeding as soon as possible, preferably on the first day of life.

\section{Caloric requirements}

The estimated daily energy accretion in utero is approximately $24 \mathrm{kcal} / \mathrm{kg} /$ day during the $24-28$ weeks of gestation, rising slightly up to approximately $38 \mathrm{kcal} / \mathrm{kg} /$ day for the remaining period of gestation (Denne 2001). Metabolic demands of very preterm newborns are high; their energy reserves are limited and quickly depleted. An infant aged 24 gestational weeks weighing $500 \mathrm{~g}$ has only $<1 \%$ of body fat and $90 \%$ of the body consists of water. There is an estimate that the energy supply in an infant weighing 1,000 g serves only for 4-5 days (Embleton 2007). Due to the large relative surface area heat loss happens at a faster rate; therefore more energy is expended for thermogenesis. Perinatal infection, lung disease and other pathologies often affecting extremely low birth weight infants (ELBWI) result in even higher consumption of energy. In a premature infant the total energy expenditure can exceed $60 \mathrm{kcal} / \mathrm{kg} /$ day, rising up to $85 \mathrm{kcal} / \mathrm{kg} /$ day in ELBWI (Koletzko et al. 2005). The energy requirement 
in ELBWI increases along with the postconceptional age and it is up to $111 \mathrm{kcal} / \mathrm{kg} /$ day $(89+/-22 \mathrm{kcal} / \mathrm{kg} /$ day $)$ in the 34-38th week, which is in about $55 \%$ higher than in term infants (Guilfoy et al. 2008). The minimal energy intake should not be lower than $110 \mathrm{kcal} / \mathrm{g} /$ day to meet all the energetic demands but even higher intake (up to $120 \mathrm{kcal} / \mathrm{kg} / \mathrm{day}$ ) may be needed to facilitate maximum protein accretion for optimal growth (Koletzko et al. 2005). Based on current data, $110-135 \mathrm{kcal} / \mathrm{g} /$ day is the most appropriate range of energy requirements in a growing premature newborn on full enteral feeding (Hulzebos and Sauer 2007, Agostoni et al. 2010). In case of total parenteral nutrition, the recommendations are lower, about $90-100 \mathrm{kcal} / \mathrm{kg} / \mathrm{day}$, since no energy is expended for digestion and none is lost in stools (Koletzko et al. 2005). Low energy supply during the first 4 weeks after birth has been identified in a recent study as an independent risk factor for ROP also suggesting that the minimum recommended parenteral caloric intake lower than $110 \mathrm{kcal} / \mathrm{kg} /$ day might be insufficient. According to their findings, the increase in caloric intake by $10 \mathrm{kcal} / \mathrm{kg} /$ day during the first month can decrease the risk of severe ROP by $24 \%$ (Stoltz Sjöström et al. 2016).

\section{Amino acids}

The sufficient intake of amino acids (AA) is essential for protein synthesis and growth. The minimum daily intake of AA to prevent catabolism is about $1.5 \mathrm{~g} / \mathrm{kg}$ (Embleton 2007). Positive nitrogen balance and adequate protein accretion for optimal growth is achieved by administration of $2.0-3.5 \mathrm{~g} / \mathrm{kg} /$ day of AA from the first day. The amount of AA should be increased to the target of 4.0-4.5 g/kg/day (Agostoni et al. 2010, Patel and Bhatia 2017) together with sufficient caloric intake to cover their metabolism.

In the past AA were administered with great caution, mostly out of concern that early AA intake may cause hyperammonemia, excessive uremia and metabolic acidosis. The explanation for these adverse effects may be probably the composition of the first AA solutions (te Braake et al. 2005). It has been shown, that blood urea nitrogen (BUN) levels do not correlate with early parenteral protein intake in VLBW infants and have the tendency to steady decrease despite the high AA intake (Ridout et al. 2004, Roggero et al. 2010). Restriction of AA intake below $4.0 \mathrm{~g} / \mathrm{kg} /$ day did not have any significance in prevention of BUN increase (Weintraub et al. 2015). Metabolic acidosis seems to develop in ELBW infants during the first days of life regardless the dosage and duration of AA administration (Jadhav et al. 2007).

In current practice the early administration of AA is recommended, it can be well tolerated immediatly after birth and has been shown to promote weight gain, protein accretion, anabolism and positive nitrogen balance. Several comparative studies did not reveal any adverse effects of AA on the metabolism and it is deemed that the early high intake of AA is safe for preterm infants (Valentine et al. 2009, Lee et al. 2013, Hay and Thureen 2010).

Despite of these benefits there are also reports concerning the risks of early high intake of AA. One possible adverse effect that has been noted in recent studies is the influence of high AA doses on the metabolism of phosporus and calcium. Hypophosphatemia and hypercalcemia were detected and attributed to a form of refeeding syndrome triggered by high AA intake, without sufficient supplementation of other micronutrients (Mizumoto et al. 2012, Ichikawa et al. 2012, Nesargi et al. 2012). Refeeding syndrome is defined as a metabolic syndrome induced by a rapid anabolism caused by increased insulin secretion after sudden nutritent intake following previous starvation or malnutrition. The results are hypophosphatemia, hypokalemia, hypomagnesemia, arrhytmia, edema and congestive heart failure. Its incidence in children is not well known, however the hypophosphatemia in preterm newborns seems to happen on a similar basis. During the anabolic stage, in a growing infant, the phosphorus uptake by the cells is increased. After depletion of phosphorus in plasma it is released from bones along with calcium, causing subsequent hypercalcemia as well (Bonsante et al. 2013).

Even though there is increasing evidence of the short-term benefits of early aggressive AA adminstration, the data concerning the long-term outcomes is still missing.

\section{Glucose}

Glucose is a major source of energy for immature brain. It serves also as a substrate for the synthesis of fatty acids and nonessential amino acids and the energy released by 1 gram is $4 \mathrm{kcal}$. Preterm infants have higher endogenous glucose production than healthy term infants; it can reach up to $8.3 \mathrm{mg} / \mathrm{kg} / \mathrm{min}$ (Koletzko et al. 2005). To match to this increased endogenous production, an adequate intake of intravenous glucose is $6-8 \mathrm{mg} / \mathrm{kg} / \mathrm{min}$ started shortly after birth (Hay 2008). 
Careful monitoring of glycemic status is essential, since even the recommended infusion rate might cause hyperglycemia (Hay 2013). Higher serum glucose concentration has other adverse effects, such as increased serum osmolarity, osmotic diuresis and increased fat deposition resulting in liver steatosis, since the excess glucose is stored as fat. The added metabolic processes further increase energy expenditure (Fusch et al. 2009).

Hyperglycemia is a common complication in extremely preterm infants and it may develop in more than $50-80 \%$ out of ELBWI due to various reasons: excessive glucose intake, as a response to stress, thermal instability, sepsis, severe illness, corticosteroid therapy, and others (Hays et al. 2006, van der Lugt et al. 2010). Hyperglycemia is regarded as a significant risk factor of neonatal morbidity and mortality, increasing the risk of early death, sepsis, severe intraventricular hemorrhage and also ROP (Hays et al. 2006, Kao et al. 2006).

The exact mechanisms of hyperglycemia induced retinal injury have not been fully identified yet. The research in diabetic retinopathy has shown that elevated glucose levels promote the oxidative stress by increased production of superoxide anion and hydrogen peroxide in the retinal cells (Ellis et al. 2000, Du et al. 2003). Additionally, the high blood glucose concentration seems to further upregulate VEGF production in retinal Müller cells during hypoxic conditions, promoting the proliferative phase of ROP (Brooks et al. 1998). The VEGF upregulation is even more significant if a period of hyperglycemia is followed by a sudden drop in glucose levels (Sone et al. 1996), as might happen in case of intravenous insulin therapy.

Many studies have focussed on the correlation between hyperglycemia and ROP suggesting persistent hyperglycemia to be an independent risk factor for the onset of the disease (Mohamed et al. 2013, Mohsen et al. 2014, Ahmadpour-Kacho et al. 2014, Chavez-Valdez et al. 2011). However the recent meta-analysis has concluded that a direct causality between hyperglycemia alone and ROP cannot be ascertained and that more studies are needed ( $\mathrm{Au}$ et al. 2015). Despite of this, an interesting association between severe ROP and insulin therapy has been reported (Kaempf et al. 2011, Lee et al. 2016). Since the insulin therapy aggravates diabetic retinopathy and upregulates VEGF in the retina (Poulaki et al. 2002), it would be useful to pay attention also on the connection between hyperglycemia, use of insulin and ROP.
Lipids

Lipids form up to $25-40 \%$ of non-protein daily caloric intake (Koletzko et al. 2005). Providing 9 kcal per gram, they are a valuable source of energy and important source of essential fatty acids as well. The sufficient lipid intake is especially important in very preterm infants, since essential fatty acid accretion in the fetus does not occur until the third trimester and then continues up to 18 months postnatally. A preterm infant weighing less than $1,000 \mathrm{~g}$ only contains $1 \%$ of fat and will lose $1.2 \mathrm{~g} /$ day of that storage, if not supplemented with lipids (Salama et al. 2015). During the last months of gestation there is a significant placental transfer of LCPUFAs, which are essential for the correct development of the central nervous system and the retina. The omega-6 arachidonic acid (ARA), the omega-3 DHA and its precursor eicosapentaenoic acid (EPA) are of the most physiological importance. They are the ubiquitous components of phospholipid membranes and DHA and ARA are the main fatty acids of neural and vascular retinal tissue. DHA comprises about $60 \%$ of all retinal LCPUFAs and compared to other body tissues, retina contains the highest amount of DHA (Harris and Baack 2015, Marszalek and Lodish 2005, SanGiovanni and Mehta 2009). Omega-3 LCPUFAs protect the retinal tissue by providing anti-inflammatory, immunomodulatory and neuroprotective effects through their conversion to eicosanoids. They serve as building blocks, local signaling molecules and are able to regulate gene transcription. EPA down-regulates the VEGF receptor expression, contributing to retinal vascular stability and together with DHA reduces endothelial proliferation and migration via suppressing VEGF in both normoxic and hypoxic conditions (SanGiovanni and Chew 2005, Zhuang et al. 2013).

In humans there is a lack of enyzmes for de novo synthesis of omega-3 and omega-6 LCPUFAs and therefore they have to be receiveved by the diet. The foetus and later the newborn is fully dependent on the mother and gets LCPUFAs by the placental transport and then from the mother's breast milk. A premature birth prevents the infant from adequate lipid stores and along with insufficient conversion from fatty acids precursors it results in essential fatty acids deficiency in preterm newborns. Especially those infants born under the 28 week of gestation are at increased risk and the fatty acids deficiency develops within $72 \mathrm{~h}$ unless they are supplemented in the nutrition (Harris and Baack 2015). Commercially available intravenous lipid emulsions are 
either soybean oil based, which contain medium length chain fatty acids and omega-6 LCPUFAs, but are low in omega-3 LCPUFAs, or combined with fish oil, olive oil, or coconut oil, which increases the omega-3 LCPUFAs content. There is an increasing evidence, that using the latter might provide an extra step in the prevention of ROP and improvement of neurodevelopment. The connection between omega-3 LCPUFAs, mainly DHA, and decreased risk of ROP has been reported in very recent studies. The infants receiving fish oil based lipid emulsions had lower incidence of ROP and increased DHA serum levels (Beken et al. 2014, Pawlik et al. 2014, Fu et al. 2015). The early high intake of intravenous lipids has been associated with lower incidence of ROP even though the used lipid emulsion was low in omega-3 LCPUFAs (Van der Veen et al. 2013). There is the evidence that lipid preparations contanining more omega-3 LCPUFAs may be more beneficial to the nutritional status, improving the fatty acid profile, while being safe and well tolerated (Rayyan et al. 2012, Dai et al. 2016).

Based on ESPGHAN guidelines, lipid supplementation is recommended in preterm infants by continuous infusion at the rate of maximum $3 \mathrm{~g} / \mathrm{kg} /$ day, starting with $1-2 \mathrm{~g} / \mathrm{kg} /$ day on the first day with an incremental increase in lipid infusion by $0.5-1 \mathrm{~g} / \mathrm{kg} /$ day until reaching the maximum dose (Koletzko et al. 2005). Ibrahim et al. (2004) have demonstrated in their study comparing early aggressive nutrition in premature newborns with the conservative model, that lipids in the dose of $3 \mathrm{~g} / \mathrm{kg} / \mathrm{day}$ started as soon as $1 \mathrm{~h}$ after birth were well tolerated. A recent review has evaluated the possible adverse effects of intravenous lipids administration - such as hyperbilirubinemia and kernicterus, chronic lung disease aggravation, adverse effects on the immune system and many others. The authors conclude that these past concerns about lipid intake have been disproved and the benefits of early lipid intake far outweigh the possible risks (Salama et al. 2015). Another study was focused on parenteral nutrition associated cholestasis (PNAC) following early lipid and protein intake. It was found, that the current trend of aggressive early nutrition poses no significant risk of PNAC but improves the weight gain, head and longitudinal growths. The incidence of PNAC was reduced significantly due to combining the aggressive parenteral nutrition with the early enteral feeding to stimulate the bile flow (Repa et al. 2016). In summary, early parenteral lipid infusions seem to have no significant adverse effects and appear to be safe and well tolerated (Vlaardingerbroek et al. 2012).

\section{Enteral feeding}

The importance of early enteral feeding or "priming" has been well estabilished. While parenteral nutrition is essential to deliver sufficient caloric intake to the very preterm infant during the first days after birth, enteral feeding is vital to further development of the digestive tract. At around 25 weeks of gestation the fetal gut is already structurally very similar to adult one. With the villous architecture estabilished and digestive enzymes mostly functional, the gut has enough capacity to digest and tolerate enteral feeds (Newell 1996). The enteral nutrition should start as soon as possible; from the first day if the baby is hemodynamically stable (Sweet et al. 2016).

The mother's own breast milk is the best choice for any infant, immunologically and nutritionally tailored to meet the needs of a baby from the very beginning. Colostrum has an important immunologic and trophic significance, being rich in $\operatorname{IgA}$, lactoferrin, while lower in nutritive components, such as minerals and lactose (Ballard and Morrow 2013). The colostrum of mothers who delivered preterm is even richer in these immunomodulatory components, albeit with high variability (Castellote et al. 2011). The early colostrum contains also high amounts of IGF-1, IGF-2 and IGF binding proteins. During the first three days of lactation the IGF-1 level is higher in about $80 \%$ when compared to its content in mature breast milk (Eriksson et al. 1993). In addition to IGF, colostrum has a high concentration of vitamin $\mathrm{E}$, which decreases along with the continuation of lactation (Lima et al. 2014). There is also evidence that the abnormal vascularization of the retina, incidence of ROP and retinal detachment are significantly lower in very preterm infants fed by human breast milk (Manzoni et al. 2013, Ginovart et al. 2016, Okamoto et al. 2007, Maayan-Metzger et al. 2012). A very recent metaanalysis has concluded that human milk feeding promotes the physiological development of immature retina and acts as a protective factor for any stage of ROP (Zhou and Chen 2015).

Breastfeeding in preterm newborns faces many challenges and lactation in mothers may often be insufficient. Preterm formulas and banked human milk are used as substitutes, while the discussion on which one is the better choice continues. In 2014 the Cochrane meta-analysis evaluated several controlled trials 
comparing the nutritional and developmental outcomes of formula fed infants versus donor milk fed infants, but the results were inconclusive. The formula fed infants displayed greater linear weight gain and head growth than the donor milk fed group, but there were no significant differences in post-discharge weight and development. Most of the studies showed an increased incidence of necrotising enterocolitis in formula fed infants along with feeding intolerance (Quigley and McGuire 2014, Boyd et al. 2007). However the authors emphasise the need for new studies to compare the effects and long term outcomes of different enteral feeding practices since the vast majority of these reports are over 20 years old, with inconsistent methodology and small sample size. Another thing that should be considered is the different composition of modern preterm formulas. There is also a lack of reliable data on comparing the effects of formula feeds and fortified donor milk.

Banked milk needs to be processed to eliminate potential pathogens and pasteurisation greatly influences its composition. The standard protocol is the Holder pasteurisation at $62.5^{\circ} \mathrm{C}$ for $30 \mathrm{~min}$. Its effects on various nutrients and bioactive components of milk differ. Certain components are significantly affected by pasteurization, such as interferon- $\gamma$, tumor necrosis factor- $\alpha$, interleukin-1 $\beta$ and interleukin-10 (Ewaschuk et al. 2011). The levels of IgA, lactoferrine and lysozyme are significantly decreased suggesting lowered efficacy of antimicrobial properties in processed donor milk (Czank et al. 2009, Tully et al. 2001). The content of LCPUFAs in pasteurized milk is not affected by Holder pasteurization and the overall content of triglycerides is only slightly decreased, however milk lipases are completely destroyed by the treatment (Tully et al. 2001, Henderson et al. 1998). Glycosaminoglycans and oligosaccharides seem to be stable. Vitamins react differently to pasteurization, while fat soluble vitamins display sufficient retention; vitamin $\mathrm{C}$ concentrations are consistently reduced. Even though the nutritional value of donor milk seems to be preserved, some immunoactive properties and enzymatic activity are lost by the heat treatment (Peila et al. 2016). Moreover, banked human milk is usually donated by mothers of healthy term infants, who have already been lactating for a longer period of time. Just like there is a compositional difference between early milk and mature milk, foremilk and hind milk, the milk of mothers who delivered preterm and the mothers of term infants also differs. Preterm milk has higher initial content of protein, fat, amino acids, calcium and sodium (Underwood 2013, Narang et al.
2006). Donor milk is low in DHA and amino acids (Valentine et al. 2010). This suggests that donor breast milk as a substitute for mother's own milk does not hold a significant advantage over the preterm formula, and that formula might better succeed in a consistent delivery of the required nutrients, without the added need for treatment.

The trials taking ROP into consideration have not found any significant difference in the incidence of ROP in both groups (14\% in formula fed infants vs. $19 \%$ in donor milk fed infants), suggesting no benefits of donor milk feeding in terms of prevention of ROP (Schanler et al. 2005, Cristofalo et al. 2013). Increased content of essential fatty acids in infant formula may mitigate the DHA insufficiency in preterm infants. A daily enteral DHA supplementation from the first week of life on seems to increase circulating DHA levels that may have a positive impact on the neurodevelopment without any adverse effects (Baack et al. 2016).

\section{Conclusions}

During the second half of pregnancy the fetus accumulates large amounts of nutrients to ensure intensive growth and normal development. After preterm birth the newborn has to cope with new environment and conditions. Due to high energy consumption and low caloric reserves, extremely preterm newborns are greatly predisposed to nutritional deficiency. There is overwhelming evidence that poor status of nutrition in these patients, mainly during the first 4 weeks of postnatal life, influences negatively their outcome including development of retina. The current strategy to provide optimal nutrition in preterm newborns is aimed to mimic the intrauterine nutrient intake corresponding to the gestational age. In the past, early aggressive nutrition was not used in premature infants because of concerns over its safety. Multiple studies have been conducted and confirmed the efficiency and tolerability of this type of nutritive support. Initiation of parenteral nutrition with high contents of amino acids, lipids and glucose shortly after birth and its combination with early enteral feeding with preferably mother's own colostrum as soon as possible, is the current standard of practice. Optimalised nutrition enables to maintain sufficient IGF-1 levels necessary for the correct development of retinal vasculature, for better protein accretion, weight gain, head growth and longitudinal growth as well. Maternal breast milk is the preferred feed for its high content of antioxidants and IGF-1. If unavailable, a preterm formula 
seems to be the next best choice compared to banked donor milk. Despite the benefits of early aggressive nutrition strategy, more studies assessing its long term effects on further development and metabolism are neeeded. However, the early aggressive nutrition serves as a relatively well achievable way to lower the burden of prematurity and its consequences on the newborn's health in the future.

\section{Conflict of Interest}

There is no conflict of interest.

\section{Acknowledgements}

This work was supported by the projects „Center of Excellence for Perinatological Research II“, co-financed from EU sources and by VEGA 1/0100/15.

\section{References}

AGOSTONI C, BUONOCORE G, CARNIELLI VP, DE CURTIS M, DARMAUN D, DECSI T, DOMELLÖF M, EMBLETON ND, FUSCH C, GENZEL-BOROVICZENY O, ET AL.: Enteral nutrient supply for preterm infants: commentary from the European Society for Paediatric Gastroenterology, Hepatology, and Nutrition Committee on Nutrition. J Pediatr Gastroenterol Nutr 50: 85-91, 2010.

AHMADPOUR-KACHO M, JASHNI MOTLAGH A, RASOULINEJAD SA, JAHANGIR T, BIJANI A, ZAHED PASHA Y: Correlation between hyperglycemia and retinopathy of prematurity. Pediatr Int 56: 726-730, 2014.

ALLEGAERT K, VANHOLE C, CASTEELS I, NAULAERS G, DEBEER A, COSSEY V, DEVLIEGER H: Perinatal growth characteristics and associated risk of developing threshold retinopathy of prematurity. J AAPOS 7: 34-37, 2003.

AU SC, TANG SM, RONG SS, CHEN LJ, YAM JC: Association between hyperglycemia and retinopathy of prematurity: a systemic review and meta-analysis. Sci Rep 5: 9091, 2015.

BAACK ML, PUUMALA SE, MESSIER SE, PRITCHETT DK, HARRIS WS: Daily enteral DHA supplementation alleviates deficiency in premature infants. Lipids 51: 423-433, 2016.

BALLARD O, MORROW AL: Human milk composition: nutrients and bioactive factors. Pediatr Clin North Am 60: 49-74, 2013.

BEHARRY KD, CAI CL, SHARMA P, BRONSHTEIN V, VALENCIA GB, LAZZARO DR, ARANDA JV: Hydrogen peroxide accumulation in the choroid during intermittent hypoxia increases risk of severe oxygen-induced retinopathy in neonatal rats. Invest Ophthalmol Vis Sci 54: 7644-7657, 2013.

BEKEN S, DILLI D, FETTAH ND, KABATAŞ EU, ZENCIROĞLU A, OKUMUŞ N: The influence of fish-oil lipid emulsions on retinopathy of prematurity in very low birth weight infants: A randomized controlled trial. Early Hum Dev 90: 27-31, 2014.

BONSANTE F, IACOBELli S, LATORRE G, RIGO J, DE FELICE C, ROBILLARD PY, GOUYON JB: Initial amino acid intake influences phosphorus and calcium homeostasis in preterm infants - it is time to change the composition of the early parenteral nutrition. PLoS One 8: e72880, 2013.

BOYD CA, QUIGLEY MA, BROCKLEHURST P: Donor breast milk versus infant formula for preterm infants: systematic review and meta-analysis. Arch Dis Child Fetal Neonatal Ed 92: 169-175, 2007.

BROOKS SE, GU X, KAUFMANN PM, MARCUS DM, CALDWELL RB: Modulation of VEGF production by pH and glucose in retinal Muller cells. Curr Eye Res 17: 875-882, 1998.

CASTELLOTE C, CASILlAS R, RAMÍREZ-SANTANA C, PÉREZ-CANO FJ, CASTELL M, MORETONES MG, LÓPEZ-SABATER MC, FRANCH A: Premature delivery influences the immunological composition of colostrum and transitional and mature human milk. J Nutr 141: 1181-1187, 2011.

CAVALLARO G, FILIPPI L, BAGNOLI P, LA MARCA G, CRISTOFORI G, RAFFAELI G, PADRINI L, ARAIMO G, FUMAGALLI M, GROPPO M, ET AL.: The pathophysiology of retinopathy of prematurity: an update of previous and recent knowledge. Acta Ophthalmol 92: 2-20, 2014.

CHAVEZ-VALDEZ R, MCGOWAN J, CANNON E, LEHMANN CU: Contribution of early glycemic status in the development of severe retinopathy of prematurity in a cohort of ELBW infants. J Perinatol 31: 749-756, 2011. 
CRISTOFALO EA, SCHANLER RJ, BLANCO CL, SULLIVAN S, TRAWOEGER R, KIECHL-KOHLENDORFER U, DUDELL G, RECHTMAN, DJ, LEE ML, LUCAS A, ABRAMS S: Randomized trial of exclusive human milk versus preterm formula diets in extremely premature infants. J Ped 163: 1592-1595, 2013.

CZANK C, PRIME DK, HARTMANN B, SIMMER K, HARTMANN PE: Retention of the immunological proteins of pasteurized human milk in relation to pasteurizer design and practice. Pediatr Res 66: 374-379, 2009.

DAI YJ, SUN LL, LI MY, DING CL, SU YC, SUN LJ, XUE SH, YAN F, ZHAO C, WANG W: Comparison of formulas based on lipid emulsions of olive oil, soybean oil, or several oils for parenteral nutrition: a systematic review and meta-analysis. Adv Nutr 7: 279-286, 2016.

DARLOW BA, HUTCHINSON JL, HENDERSON-SMART DJ, DONOGHUE DA, SIMPSON JM, EVANS NJ: Prenatal risk factors for severe retinopathy of prematurity among very preterm infants of the Australian and New Zealand Neonatal Network. Pediatrics 115: 990-996, 2005.

DENNE SC: Protein and energy requirements in preterm infants. Semin Neonatol 6: 377-382, 2001.

DU Y, MILLER CM, KERN T: Hyperglycemia increases mitochondrial superoxide in retina and retinal cells. Free Radic Biol Med 35: 1491-1499, 2003.

ELLIS EA, GUBERSKI DL, SOMOGYI-MANN M, GRANT MB: Increased H2O2, vascular endothelial growth factor and receptors in the retina of the BBZ/WOR diabetic rat. Free Radic Biol Med 28: 91-101, 2000.

EMBLETON ND: Optimal protein and energy intakes in preterm infants. Early Hum Dev 83: 831-837, 2007.

ERIKSSON U, DUC G, FROESCH ER, ZAPF J: Insulin-like growth factors (IGF) I and II and IGF binding proteins (IGFBPs) in human colostrum/transitory milk during the 1st week postpartum: comparison with neonatal and maternal serum. Biochem Biophys Res Commun 196: 267-273, 1993.

EWASCHUK JB, UNGER S, O'CONNOR DL, STONE D, HARVEY S, CLANDININ MT, FIELD CJ: Effect of pasteurization on selected immune components of donated human breast milk. J Perinatol 31: 593-598, 2011.

FOWDEN AL: The insulin-like growth factors and feto-placental growth. Placenta 24: 803-812, 2003.

FU Z, LOFQVIST CA, SHAO Z, SUN Y, JOYAL JS, HURST CG, CUI RZ, EVANS LP, TIAN K, SANGIOVANNI JP, ET AL:: Dietary $\omega-3$ polyunsaturated fatty acids decrease retinal neovascularization by adiposeendoplasmic reticulum stress reduction to increase adiponectin. Am J Clin Nutr 101: 879-888, 2015.

FUSCH C, BAUER K, BÖHLES HJ, JOCHUM F, KOLETZKO B, KRAWINKEL M, KROHN MÜHLEBACH S, WORKING GROUP FOR DEVELOPING THE GUIDELINES FOR PARENTERAL NUTRITION OF THE GERMAN SOCIETY FOR NUTRITIONAL MEDICINE: Neonatology/Paediatrics - Guidelines on Parenteral Nutrition, Chapter 13. GMS German Medical Science 7: Doc15, 2009.

GERGELY K, GERINEC A: Retinopathy of prematurity--epidemics, incidence, prevalence, blindness. Bratisl Lek Listy 111: 514-517, 2010.

GINOVART G, GICH I, VERD S: Human milk feeding protects very low-birth-weight infants from retinopathy of prematurity: a pre-post cohort analysis. J Matern Fetal Neonatal Med 29: 3790-3795, 2016.

GOGATE P, GILBERT C, ZIN A: Severe visual impairment and blindness in infants: causes and opportunities for control. Middle East Afr J Ophthalmol 18: 109-114, 2011.

GUILFOY VM, WRIGHT-COLTART S, LEITCH CA, DENNE SC: Energy expenditure in extremely low birth weight infants near time of hospital discharge. J Pediatr 153: 612-615, 2008.

HÅRD A-L, SMITH LE, HELLSTRÖM A: Nutrition, insulin-like growth factor-1 and retinopathy of prematurity. Sem Fetal Neonatal Med 18: 136-142, 2013.

HARRIS W, BAACK M: Beyond building better brains: bridging the docosahexaenoic acid (DHA) gap of prematurity. J Perinatol 35: 1-7, 2015.

HARTNETT ME: Pathophysiology and mechanisms of severe retinopathy of prematurity. Ophthalmology 122: 200-210, 2015.

HAY WW, THUREEN P: Protein for preterm infants: how much is needed? How much is enough? How much is too much? Pediatr Neonatol 51: 198-207, 2010.

HAY WW: Strategies for feeding the preterm infant. Neonatology 94: 245-254, 2008.

HAY WW: Aggressive nutrition of the preterm infant. Curr Pediatr Rep 1: 229-239, 2013.

HAYS SP, SMITH EO, SUNEHAG AL: Hyperglycemia is a risk factor for early death and morbidity in extremely low birth-weight infants. Pediatrics 118: 1811-1818, 2006. 
HELLSTRÖM A, LEY D, HANSEN-PUPP I, NIKLASSON A, SMITH L, LÖFQVIST C, HÅRD AL: New insights into the development of retinopathy of prematurity - importance of early weight gain. Acta Pcediatr 99: 502-508, 2010.

HELLSTROM A, PERRUZZI C, JU M, ENGSTROM E, HARD AL, LIU JL, ALBERTSSON-WIKLAND K, CARLSSON B, NIKLASSON A, SJODELL L, ET AL.: Low igf-i suppresses vegf-survival signaling in retinal endothelial cells: Direct correlation with clinical retinopathy of prematurity. Proc Natl Acad Sci U S A 98: 5804-5808, 2001.

HENDERSON TR, FAY TN, HAMOSH M: Effect of pasteurization on long chain polyunsaturated fatty acid levels and enzyme activities of human milk. J Pediatr 132: 876-878, 1998.

HULZEBOS CV, SAUER PJ: Energy requirements. Semin Fetal Neonatal Med 12: 2-10, 2007.

IBRAHIM HM, JEROUDI MA, BAIER RJ, DHANIREDDY R, KROUSKOP RW: Aggressive early total parental nutrition in low-birth-weight Infants. J Perinatol 24: 482-486, 2004.

ICHIKAWA G, WATABE Y, SUZUMURA H, SAIRENCHI T, MUTO T, ARISAKA O: Hypophosphatemia in small for gestational age extremely low birth weight infants receiving parenteral nutrition in the first week after birth. J Pediatr Endocrinol Metab 25: 317-321, 2012.

INTERNATIONAL COMMITTEE FOR THE CLASSIFICATION OF RETINOPATHY OF PREMATURITY: The international classification of retinopathy of prematurity revisited. Arch Ophthalmol 123: 991-999, 2005.

JADHAV P, PARIMI PS, KALHAN SC: Parenteral amino acid and metabolic acidosis in premature infants. J Parenter Enteral Nutr 31: 278-283, 2007.

KAEMPF JW, KAEMPF AJ, WU Y, STAWARZ M, NIEMEYER J, GRUNKEMEIER G: Hyperglycemia, insulin and slower growth velocity may increase the risk of retinopathy of prematurity. $J$ Perinatol 31: 251-257, 2011.

KAO LS, MORRIS BH, LALLY KP, STEWART CD, HUSEBY V, KENNEDY KA: Hyperglycemia and morbidity and mortality in extremely low birth weight infants. J Perinatol 26: 730-736, 2006.

KIM YW, BYZOVA TV: Oxidative stress in angiogenesis and vascular disease. Blood 123: 625-631, 2014.

KOLETZKO B, GOULET O, HUNT J, KROHN K, SHAMIR R, PARENTERAL NUTRITION GUIDELINES WORKING GROUP, EUROPEAN SOCIETY FOR CLINICAL NUTRITION AND METABOLISM, EUROPEAN SOCIETY OF PAEDIATRIC GASTROENTEROLOGY, HEPATOLOGY AND NUTRITION (ESPGHAN), EUROPEAN SOCIETY OF PAEDIATRIC RESEARCH (ESPR): Guidelines on Paediatric Parenteral Nutrition of the European Society of Paediatric Gastroenterology, Hepatology and Nutrition (ESPGHAN) and the European Society for Clinical Nutrition and Metabolism (ESPEN), supported by the European Society of Paediatric Research (ESPR). J Pediatr Gastroenterol Nutr 41 (Suppl 2): S1-S87, 2005.

LASSARRE C, HARDOUIN S, DAFFOS F, FORESTIER F, FRANKENNE F, BINOUX M: Serum insulin-like growth factors and insulin-like growth factor binding proteins in the human fetus. Relationships with growth in normal subjects and in subjects with intrauterine growth retardation. Pediatr Res 29: 219-225, 1991.

LEE HJ, PARK J, KIM CR, SEOL IJ, PARK HK: Blood urea nitrogen concentration and aggressive parenteral amino acid administration in extremely low birth weight infants during the first week. Korean J Perinatol 24: 20-28, 2003.

LEE JH, HORNIK CP, TESTONI D, LAUGHON MM, COTTEN CM, MALDONADO RS, SMITH PB: Insulin, hyperglycemia, and severe retinopathy of prematurity in extremely low-birth-weight infants. Amer J Perinatol 33: 393-400, 2016.

LIMA MS, DIMENSTEIN R, RIBEIRO KD: Vitamin E concentration in human milk and associated factors: a literature review. J Pediatr (Rio J) 90: 440-448, 2014.

LÖFQVIST C, ENGSTRÖM E, SIGURDSSON J, HÅRD AL, NIKLASSON A, EWALD U, HOLMSTRÖM G, SMITH LE, HELLSTRÖM A: Postnatal head growth deficit among premature infants parallels retinopathy of prematurity and insulin-like growth factor-1 deficit. Pediatrics 117: 1930-1938, 2006.

MAAYAN-METZGER A, AVIVI S, SCHUSHAN-EISEN I, KUINT J: Human milk versus formula feeding among preterm infants: short-term outcomes. Amer J Perinatol 29: 121-126, 2012.

MANZONI P, STOLFI I, PEDICINO R, VAGNARELLI F, MOSCA F, PUGNI L, BOLLANI L, POZZI M, GOMEZ K, TZIALLA C, ET AL.: Human milk feeding prevents retinopathy of prematurity (ROP) in preterm VLBW neonates. Early Hum Dev 89: 64-68, 2013. 
MARSZALEK JR, LODISH HF: Docosahexaenoic acid, fatty acid-interacting proteins, and neuronal function: breastmilk and fish are good for you. Annu Rev Cell Dev Biol 21: 633-657, 2005.

MIZUMOTO H, MIKAMI M, ODA H, HATA D: Refeeding syndrome in a small-for-dates micro-preemie receiving early parenteral nutrition. Pediatr Int 54: 715-717, 2012.

MOHAMED S, MURRAY JC, DAGLE JM, COLAIZY T: Hyperglycemia as a risk factor for the development of retinopathy of prematurity. BMC Pediatrics 13: 78, 2013.

MOHSEN L, ABOU-ALAM M, EL-DIB M, LABIB M, ELSADA M, ALY H: A prospective study on hyperglycemia and retinopathy of prematurity. J Perinatol 34: 453-457, 2014.

NARANG APS, BAINS HS, KANSAL S, SINGH D: Serial composition of human milk in preterm and term mothers. Indian J Clin Biochem 21: 89-94, 2006.

NESARGI SV, BHAT SR, RAO P N S, IYENGAR A: Hypercalcemia in extremely low birth weight neonates. Indian J Pediatr 79: 124-126, 2012.

NEWELL SJ: Gastrointestinal function and its ontogeny: how should we feed the preterm infant? Sem Neonatol 1: 59-66, 1996.

OKAMOTO T, SHIRAI M, KOKUBO M, TAKAHASHI S, KAJINO M, TAKASE M, SAKATA H, OKI J: Human milk reduces the risk of retinal detachment in extremely low-birthweight infants. Pediatr Int 49: 894-897, 2007.

PATEL P, BHATIA J: Total parenteral nutrition for the very low birth weight infant. Semin Fetal Neonatal Med 22: 2-7, 2017.

PAWLIK D, LAUTERBACH R, WALCZAK M, HURKAŁA J, SHERMAN MP: Fish-oil fat emulsion supplementation reduces the risk of retinopathy in very low birth weight infants: a prospective, randomized study. J Parenteral Enteral Nutr 38: 711-716, 2014.

PEILA C, MORO GE, BERTINO E, CAVALLARIN L, GIRIBALDI M, GIULIANI F, CRESI F, COSCIA A: The effect of holder pasteurization on nutrients and biologically-active components in donor human milk: a review. Nutrients 8: 477, 2016.

PORCELLI PJ, WEAVER RG JR: The influence of early postnatal nutrition on retinopathy of prematurity in extremely low birth weight infants. Early Hum Dev 86: 391-396, 2010.

POULAKI V, QIN W, JOUSSEN AM, HURLBUT P, WIEGAND SJ, RUDGE J, YANCOPOULOS G, ADAMIS AP: Acute intensive insulin therapy exacerbates diabetic blood-retinal barrier breakdown via hypoxia-inducible factor-1 $\alpha$ and VEGF. $J$ Clin Invest 109: 805-815, 2002.

QUIGLEY M, MCGUIRE W: Formula versus donor breast milk for feeding preterm or low birth weight infants. Cochrane Database Syst Rev 4, CD002971, 2014.

RAYYAN M, DEVLIEGER H, JOCHUM F, ALLEGAERT K: Short-term use of parenteral nutrition with a lipid emulsion containing a mixture of soybean oil, olive oil, medium-chain triglycerides, and fish oil: a randomized double-blind study in preterm infants. JPEN J Parenter Enteral Nutr 36 (1 Suppl): 81S-94S, 2012.

REPA A, LOCHMANN R, UNTERASINGER L, WEBER M, BERGER A, HAIDEN N: Aggressive nutrition in extremely low birth weight infants: impact on parenteral nutrition associated cholestasis and growth. PeerJ 4: e2483, 2016.

RIDOUT E, MELARA D, ROTTINGHAUS S, THUREEN PJ: Blood urea nitrogen concentration as a marker of amino-acid intolerance in neonates with birthweight less than 1250 g. J Perinatol 25: 130-133, 2004.

ROGGERO P, GIANNİ ML, MORLACCHI L, PIEMONTESE P, LIOTTO N, TARONI F, MOSCA F: Blood urea nitrogen concentrations in low-birth-weight preterm infants during parenteral and enteral nutrition. $J$ Pediatr Gastroenterol Nutr 51: 213-215, 2010.

SALAMA GS, KAABNEH MA, ALMASAEED MN, ALQURAN MI: Intravenous lipids for preterm infants: a review. Clin Med Insights Pediatr 9: 25-36, 2015.

SANGIOVANNI JP, CHEW EY: The role of omega-3 long-chain polyunsaturated fatty acids in health and disease of the retina. Prog Retin Eye Res 24: 87-138, 2005.

SANGIOVANNI JP, MEHTA S: Variation in lipid-associated genes as they relate to risk of advanced age-related macular degeneration. In: Omega-3 Fatty Acids, the Brain and Retina. SIMOPOULOS AP, BAZÁN NG (eds), S Karger Ag, Basel, 2009, pp 55-64. 
SAPIEHA P, JOYAL JS, RIVERA JC, KERMORVANT-DUCHEMIN E, SENNLAUB F, HARDY P, LACHAPELLE P, CHEMTOB S: Retinopathy of prematurity: understanding ischemic retinal vasculopathies at an extreme of life. J Clin Invest 120: 3022-3032, 2010.

SCHANLER RJ, LAU C, HURST NM, SMITH EO: Randomized trial of donor human milk versus preterm formula as substitutes for mothers' own milk in the feeding of extremely premature infants. Pediatrics 116: 400-406, 2005.

SONE H, KAWAKAMI Y, OKUDA Y, KONDO S, HANATANI M, SUZUKI H, YAMASHITA K: Vascular endothelial growth factor is induced by long-term high glucose concentration and up-regulated by acute glucose deprivation in cultured bovine retinal pigmented epithelial cells. Biochem Biophys Res Commun 221: 193-198, 1996.

STOLTZ SJÖSTRÖM E, LUNDGREN P, ÖHLUND I, HOLMSTRÖM G, HELLSTRÖM A, DOMELLÖF M: Low energy intake during the first 4 weeks of life increases the risk for severe retinopathy of prematurity in extremely preterm infants. Arch Dis Child Fetal Neonatal Ed 101: F108-F113, 2016.

SWEET DG, CARNIELLI V, GREISEN G, HALLMAN M, OZEK E, PLAVKA R, SAUGSTAD OD, SIMEONI U, SPEER CP, VENTO M, VISSER GH, HALLIDAY HL: European consensus guidelines on the management of respiratory distress syndrome - 2016 update. Neonatology 111: 107-125, 2017.

TE BRAAKE FW, VAN DEN AKKER CH, WATTIMENA DJ, HUIJMANS JG, VAN GOUDOEVER JB: Amino acid administration to premature infants directly after birth. $J$ Pediatr 147: 457-461, 2005.

TULLY DB, JONES F, TULLY MR: Donor milk: what's in it and what's not. J Hum Lact 17: 152-155, 2001.

UNDERWOOD MA, GILBERT WM, SHERMAN MP: Amniotic fluid: not just fetal urine anymore. J Perinatol 25: 341-348, 2005.

UNDERWOOD MA: Human milk for the premature infant. Pediatr Clin North Am 60: 189-207, 2013.

VALENTINE CJ, FERNANDEZ S, ROGERS LK, GULATI P, HAYES J, LORE P, PUTHOFF T, DUMM M, JONES A, COLLINS K, ET AL.: Early amino-acid administration improves preterm infant weight. $J$ Perinatol 29: 428-432, 2009.

VALENTINE CJ, MORROW G, FERNANDEZ S, GULATI P, BARTHOLOMEW D, LONG D, WELTY SE, MORROW AL, ROGERS LK: Docosahexaenoic acid and amino acid contents in pasteurized donor milk are low for preterm infants. J Pediatr 157: 906-910, 2010.

VAN DER LUGT NM, SMITS-WINTJENS VE, VAN ZWIETEN PH, WALTHER FJ: Short and long term outcome of neonatal hyperglycemia in very preterm infants: a retrospective follow-up study. BMC Pediatr 10: 52, 2010.

VAN DER VEEN DK, MARTIN CR, MEHENDALE R, ALLRED EN, DAMMANN O, LEVITON A, ELGAN STUDY INVESTIGATORS: Early nutrition and weight gain in preterm newborns and the risk of retinopathy of prematurity. PLoS One 8: e64325, 2013.

VLAARDINGERBROEK H, VELDHORST MA, SPRONK S, VAN DEN AKKER CH, VAN GOUDOEVER JB: Parenteral lipid administration to very-low-birth-weight infants--early introduction of lipids and use of new lipid emulsions: a systematic review and meta-analysis. Am J Clin Nutr 96: 255-268, 2012.

WEINTRAUB AS, BLANCO V, BARNES M, GREEN RS: Impact of renal function and protein intake on blood urea nitrogen in preterm infants in the first 3 weeks of life. J Perinatol 35: 52-56, 2015.

WILKINSON AR, HAINES L, HEAD K, FIELDER AR: UK retinopathy of prematurity guideline. Early Hum Dev 84: 71-74, 2008.

WU C, LÖFQVIST C, SMITH LE, VAN DER VEEN DK, HELLSTRÖM A, WINROP CONSORTIUM: Importance of early postnatal weight gain for normal retinal angiogenesis in very preterm infants: a multicenter study analyzing weight velocity deviations for the prediction of retinopathy of prematurity. Arch Ophthalmol 130: 992-999, 2012.

ZHOU J, SHUKLA VV, JOHN D, CHEN C: Human milk feeding as a protective factor for retinopathy of prematurity: a meta-analysis. Pediatrics 136: e1576-1586, 2015.

ZHUANG W, WANG G, LI L, LIN G, DENG Z: Omega-3 polyunsaturated fatty acids reduce vascular endothelial growth factor production and suppress endothelial wound repair. J Cardiovasc Transl Res 6: 287-293, 2013. 